\title{
Peluang Mata Pelajaran Ilmu Pengetahuan Sosial (IPS) Dalam Mewujudkan Pendidikan Yang Berbasis Multikultural
}

\author{
Tri Nurza Rahmawati \\ Mahasiswa S3 Prodi Ilmu Pendidikan UNP \\ e-mail:trinurzarahmawati@gmail.com
}

\begin{abstract}
Absract- This article will explain and describe the opportunities for Social Sciences subjects in realizing multicultural-based education. In compiling this article, the authors used the literature study method is data collection techniques are carried out using books, and other literatures such as journals or articles related to the theme discussed. The results showed that multicultural-based education is education that must be realized in formal education in Indonesia, departing from the conditions of people in Indonesia who have a diversity of ethnicities, cultures, and religions. Seeing all subjects in the world of education at the junior high level, Social Sciences subjects have a very strategic position. This is based on aspects of the study in the subject of Social Sciences providing a gap in almost every material. Thus, the availability of the gap is expected to be used as fully as possible and as effectively as possible in incorporating multicultural values, for the creation of multicultural-based education.
\end{abstract}

Keyword: Social Sciences, Education, Multicultural

\begin{abstract}
Abstrak- Artikel ini akan menjelaskan dan mendeskripsikan Peluang mata pelajaran Ilmu Pengetahuan Sosial (IPS) dalam mewujudkan pendidikan yang berbasis multikultural. Dalam menyusun artikel ini, penulis menggunakan metode studi pustaka yaitu teknik pengumpulan data dilakukan dengan menggunakan buku-buku, dan literatur-literatur lainnya seperti jurnal ataupun artikel yang terkait dengan tema yang dibahas. Hasil penelitian menunjukkan bahwa pendidikan berbasis multikultural merupakan pendidikan yang harus diwujudkan dalam pendidikan formal di Indonesia, berangkat dari kondisi masyarakat di Indonesia yang memiliki keragaman suku bangsa, budaya, dan agama. Melihat semua mata pelajaran dalam dunia pendidikan ditingkat SMP, mata pelajaran Ilmu Pengetahuan Sosial memiliki kedudukan yang sangat strategis. Hal ini didasari aspek kajian dalam mata pelajaran Ilmu Pengetahuan Sosial menyediakan celah hampir disetiap materi. Dengan demikian, ketersediaan celah tersebut diharapakan mampu digunakan semaksimal mungkin dan seefektif mungkin dalam memasukkan nilainilai multikultural, guna terciptanya pendidikan yang berbasis multikultural.
\end{abstract}

Kata Kunci: Ilmu Pengetahuan Sosial, Pendidikan, Multikultural

\section{A. PENDAHULUAN}

Indonesia merupakan bangsa yang memiliki keanekaragaman suku bangsa, kultur, agama yang kompleks. Kamal (2013: 2) juga mengungkapkan bahwa masyarakat Indonesia terdiri dari masyarakat yang majemuk (plural society), hal ini terlihat dari keragaman suku bangsa, agama dan kepercayaan yang berbeda-beda, serta memiliki bahasa dan corak sosial budaya yang tidak sama. Sebagai masyarakat yang menganut paham kemajemukan atau dikenal juga dengan istilah pluralisme yang diartikan sebagai paham yang kurang sepenuhnya dalam memaknai keragaman, perbedaan yang ada disetiap kelompok masyarakat. Suparlan (2014: 2) dan Syaifuddin (2006: 4) menjelaskan bahwa paham kemajemukan ini, secara mendasar mengacu kepada paham multikulturalisme. Hal ini dapat menggambarkan azaz "Bhineka Tunggal Ika" yang dibuat para 
founding father bangsa Indonesia terimplementasikan secara mengakar.

Multikulturalisme sebagai paham yang menitikberatkan kajiannya tentang relasi antar satu budaya dengan budaya lainnya mesti saling mempertimbangkan. Dari sinilah lahirnya gagasan tentang kedudukan masyarakat yang mesti setara, memiliki sikap toleran, berjiwa saling menghargai, dan sebagainya. Syaifuddin (2006: 4) juga mengungkapkan bahwa dalam mewujudkan masyarakat multikulturalisme di Indonesia secara tidak langsung mendirikan ideologyideologi yang menjunjung tinggi kesetaraan.

Multikulturalisme sebagai paham yang menerima segala wujud perbedaan dan keragaman. Nilai-nilai turunan dari konsep multikultural merupakan harapan tentang bagaimana hidup dapat saling menghormati, saling membantu saling toleransi terhadap sesama masyarakat meskipun beragam. Sehingga masyarakat dapat hidup dan berbaur dalam masyarakat yang multikultur serta menerima setiap perbedaan yang ada dalam kehidupan sosialnya.

Paham ini tentunya menjadi cerminan bagi kita sebagai masyarakat Indonesia yang hidup ditengah-tengah masyarakat yang multikultur harus bisa hidup berdampingan, saling hormat menghormati, saling menghargai dan bertoleansi tanpa mengganggu atau menggusik kelompok lain agar kita dapat hidup dengan damai dan rukun di negeri sendiri walaupun kita berbeda, kita tetap satu sesuai dengan yang dicita-citakan azaz "bhineka tunggal ikha”.
Indonesia sebagai bangsa yang multikultur, memiliki kekayaan keanekaragaman yang merupakan potensi untuk membangun negara yang besar. Namun sebaliknya, kondisi masyarakat majemuk sebagai kekayaan bangsa di sisi lain sangat rawan, dapat memicu konflik dan perpecahan. Naisbitt (1994: 15) juga menjelaskan bahwa masalah keberagaman mesti diperhatikan. Karena Indonesia sebagai Negara yang memiliki keberagaman, jika tidak dibenahi dengan baik dapat mengganggu kemanan dan ketertiban Negara.

Peradaban suatu bangsa didasari seberapa dalam pendidikan yang mereka peroleh. Hal ini sangat mempengaruhi mereka dalam mengartikan, memahami dan menyikapi kondisi keberagaman yang ada. Dalam Nasional, D. P. (2003) disebutkan bahwa suatau udaha yang dibutuhkan oleh manusia agar dapat menunjang perannya di masa yang akan datang usaha ini dilakaukan secara sadar. Sehubungan dengan itu, Sujana (2019: 2) mengungkapkan bahwa pendidikan sebagai wadah untuk mengembangkan potensi anak-anak didik secara lahir maupun batin, dari sifat kodratinya menuju kearah peradaban manusiawi dan lebih baik Lebih dari itu Idris (1987: 7) menyebutkan bahwa pendidikan adalah suatu proses yang dilakukan untuk memanusiakan manusia agar dapat memahami dirinya dan budaya yang dimilikinya.

\section{B. METODE PENELITIAN}

Dalam menyusun artikel ini, penulis menggunakan metode studi pustaka. Dimana teknik pengumpulan 
data dilakukan dengan menggunakan buku-buku, dan literature-literatur lainnya seperti jurnal ataupun artikel yang terkait dengan tema yang dibahas. Dengan cara mengutip pendapatpendapat baik dari ahli mauapun dari peneliti lain yang terdapat di dalam sumber-sumber tersebut yang kemudian digunakan untuk memperkuat landasan teori yang digunakan.

Studi kepustakan ialah segala usaha yang dilakukan oleh peneliti untuk menghimpun informasi yang relevan dengan topik atau masalah yang akan atau sedang diteliti. Informasi itu dapat diperoleh dari buku-buku ilmiah, laporan penelitian, karangan-karangan ilmiah, tesis dan disertasi, peraturanperaturan, ketetapan-ketetapan, buku tahunan, ensiklopedia dan sumbersumber tertulis baik tercetak maupun elektronik lain (Setiawan, 2017)

Dengan melakukan studi kepustakaan, peneliti dapat memanfaatkan semua informasi dan pemikiran-pemikiran yang relevan dengan penelitiannya. Untuk melakukan studi kepustakaan, perpustakaan merupakan suatu tempat yang tepat guna memperoleh bahanbahan dan informasi yang relevan untuk dikumpulkan, dibaca dan dikaji, dicatat dan dimanfaatkan.

\section{PEMBAHASAN}

Berangkat dari ungkapanungkapan diatas pendidikan yaitu adanya usaha sadar dan terencana yang dilakukan oleh pendidik kepada peserta didik agar peserta didik bisa mengembangkan potensi-potensi yang ada di dalam dirinya sehingga ia akan menjadi sosok pribadi yang berguna baik agamanya, bangssanya dan negaranya. Selain itu, pendidikan juga berarti alat dan bentuk proses budaya yang disengaja dan tujuannya adalah untuk mentransfer budaya nilai-nilai kepada individu atau masyarakat secara terencana dan terprogram. Namun, pendidikan dan sekolah perlu dipertimbangkan keragaman orang dan siswa dalam masyarakat (ras, asal etnis, kelas, jenis kelamin, bahasa, cacat fisik, dan lain sebagainya.) dan untuk mengembangkan program pendidikan yang tepat, metode pengajaran, proses, dan mekanisme. Pada posisi ini, pendidikan memegang peran yang sangat penting dalam mengelola keberagaman yang ada pada bangsa Indonesia. Sebab pendidikan ialah lapangan umum dalam usaha menerjemahkan dan menanamkan nilai-nilai multikultural. Sehingga dapat menjadikan masyarakat Indonesia yang memiliki jiwa-jiwa kebhinekaan yang tinggi. Pendidikan diharapkan mampu membangun kelenturan mental generasi di masa yang akan datang dalam menghadapi benturan konflik sosial dari dalam maupun dari luar.

Dalam memberi pembekalan atau penanaman nilai yang berkaitan dengan keberagaman, dunia pendidikan merupakan wadah yang memiliki peran penting dalam proses ini. Oleh karena itu, guru diharapkan mampu melaksanakannya lewat kreatifitas dan inovasinya dalam proses pembelajaran di kelas, diantaranya dengan cara melakukan pendekatan yang membuat peserta didik bisa menerima perannya dengan baik yaitu adanya sebuah pembelajaran yang bermakna. Sehingga proses pembelajaran menjadi tidak sia-sia, peserta didik dapat benar- 
benar mencerna pembelajaran dan pesan yang disampaikan akan melekat, bukan hanya secara kognitif, tetapi juga secara afektif dan psikomotor.

Pembekalan dan penanaman nilai-nilai multikultural dapat diterapkan dengan fasih dalam proses belajar mengajar pada mata pelajaran ilmu pengetahuan sosial karena kajian yang ada di dalam materi ilmu pengetahuan sosial sangatdekat dengan aspek-aspek dalam kehiduoan bermasyarakat. Seperti fakta yang disampaikan pada saat proses pembelajaran tidak hanya fokus ke dalam materi saja akan tetapi ada nilainilai multikultural yang disampaikan di dalam setiap materi baik itu fakta yang bersifat kontekstual ataupun konsep. Apabila proses ini dapat dikatakan sampai kepada para siswa yang dibawa untuk menelaah suatu peristiwa yang ada di dalam kehidupan bermasyarakat sehingga sekolah tidak melahirkan individu yang primodialisme, etnosetrisme dan lain sebagainya yang sama sekali tidak sejalan dengan pola kehidupan masyarakat Indonesia yang majemuk.

Peluang yang dapat dilakukan oleh mata pelajaran ilmu pengetahuan sosial dalam proses pembelajaran sangatlah banyak. Karena pada setiap materi bahkan sub materi, kajian ilmu pengetahuan sosial memiliki semua celah untuk memasukkan nilai-nilai multikultural yang ada seperti nilai persamaan hak, nilai toleransi, nilai adil, nilai persaudaraan dan nilai etika pergaulan. Salah satu contoh misalnya melalui materi sejarah praktek pendidikan multikultural dapat dilaksanakan dengan menyajikan konten atau peristiwa masa lalu yang sarat dengan keberagaman hal ini dapat dilihat dari pembelajaran sejarah lokal merupakan salah satu pembelajaran yang dapat mendukung proses pendidikan multikultural karena materi yang beragam akan membuat peserta didik semakin memahami keberagaman tersebut sebagai bentuk kekayaan yang dimiliki oleh bangsa Indonesia.

Akan tetapi proses pembelajaran Ilmu Pengetahuan Sosial yang dilaksanakan oleh pendidik kepada peserta didik sebagai siswa tidak terlaksana secara efektif dan efisien. Salah satunya terjadi karena masih kurangnya sumbangan peran guru IPS sebagai pendidik dan pengajar ditingkat SMP. Peran guru IPS sebagai pendidik dan pengajar terbukti sangat berpengaruh dalam meningkatkan nilai-nilai multikultural seperti sikap sosial yang dimiliki oleh peserta didik. Nilai-nilai tentang wawasan multikultural akan menjadi lebih efetif apabila dimasukan ke dalam bahan ajar yang digunakan dalam proses pembelajaran.

Berangkat dari fakta yang ada di lapanagan tersebut, maka sangat diperlukan pembaharuan di dalam proses pemberian materi Ilmu Pengetahuan Sosial yang di dalamnya terdapat nilai-nilai multkultural seperti nilai persamaan hak, nilai toleransi, nilai adil, nilai persaudaraan dan lain sebagainya, dimana nilai-nilai ini akan diterapkan oleh peserta didik di dalam kehidupan bermasyarakat. Ross (2011: 59) mengemukakan bahwa Ilmu Pengetahuan Sosial mempersiapkan para generasi muda sehingga mereka memiliki pengetahuan, keterampilan, dan nilai-nilai yang diperllukan agar mereka dapat hidup dan berpartisipasi aktif dalam masyarakat. 
Penulis berharap kepada para calon pendidik dan yang sudah menjadi pendidik pada mata pelajaran Ilmu Pengetahuan Sosial untuk membuat bahan ajar Ilmu Pengetahuan Sosial yang di dalamnya terdapat wawasan mengenai nilai-nilai multikultural seperti yang telah disampaikan di atas, karena sangat disayangkan apabila materi-materi Ilmu Pengetahuan Sosial yang dimuat di dalam bahan ajar tidak disusun dan dikemas secara efektif dan efisien. Sebab kajian Ilmu Pengetahuan Sosial memiliki peluang besar baik dalam media penyampaian maupun alat penyampaiannya sangat mudah diperoleh dari yang terlama hingga yang terbaru. Dengan demikian pembelajaran Ilmu Pengetahuan Sosial mampu menjadi garda terdepan dalam penanaman nilai-nilai multikulural dalam pendidikan. Selain itu, Ilmu Pengetahuan Sosial juga memiliki banyak celah untuk memasukkan nilainilai multikultural dalam setiap materi pelajarannya. Dengan kata lain materi pembelajaran Ilmu Pengetahuan Sosial sangat representatif untuk merancang bahan ajar yang berbasis multikultural, setiap kandungan yang ada pada pembelajaran Ilmu Pengetahuan Sosial dapat dikorelasikan dengan nilai-nilai multikultural.

\section{KESIMPULAN}

Pendidikan berbasis multikultural merupakan pendidikan yang harus diwujudkan dalam pendidikan formal di Indonesia. Hal ini berangkat dari kondisi masyarakat di Indonesia yang memiliki keragaman suku bangsa, budaya, dan agama. Melihat semua mata pelajaran dalam dunia pendidikan ditingkat SMP, mata pelajaran Ilmu Pengetahuan Sosial memiliki kedudukan yang sangat strategis. Hal ini didasari aspek kajian dalam mata pelajaran Ilmu Pengetahuan Sosial menyediakan celah hampir disetiap materi. Dengan demikian, ketersediaan celah tersebut diharapakan mampu digunakan semaksimal mungkin dan seefektif mungkin dalam memasukkan nilai-nilai multikultural, guna terciptanya pendidikan yang berbasis multikultural.

\section{DAFTAR PUSTAKA:}

Agbaria, A. K. (2011). The Social Studies Education Discourse Community on Globalization: Exploring the Agenda of Preparing Citizens for the Global Age. Journal of Studies in International Education. 15 (1), 59.

Lestari, G. (2016). Bhinnekha Tunggal Ika: Khasanah Multikultural Indonesia di Tengah Kehidupan Sara. Jurnal Pendidikan Pancasila dan Kewarganegaraan, 28 (1).

Naisbit, J. (1994). Global Paradox.

Jakarta: Binarupa Aksara.

Rohmat. (2016). Nilai-nilai Multikultural dalam Bahan Ajar. Jurnal Penelitian Agama JPA. 17 (1).

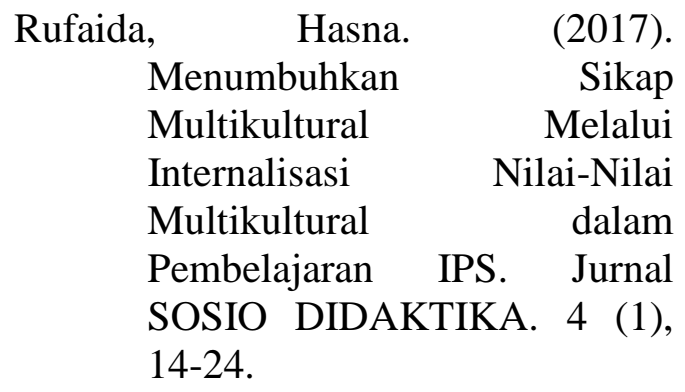


Sujana, I. W. C. (2019). Fungsi dan Tujuan Pendidikan Indonesia. Adi Widya: Jurnal Pendidikan Dasar, 4 (1), 29-39.

Suparlan, P. (2014). Menuju Masyarakat Indonesia Yang Multikultural. Antropologi Indonesia.

Suharman, Edy \& Mukminan. (2017). Peran Guru IPS sebagai Pendidik dan Pengajar dalam Meningkatkan sikap sosial dan tanggung jawab siswa SMP. Jurnal Pendidikan IPS. 4 (1) 113.

Suparman, D. (2015) Hubungan Peran Guru Sekolah Dasar Dengan Sikap Tanggung Jawab Siswa. Jurnal pedagogik. 2 (7).

Syaifuddin, A. F. (2006). Membumikan MultikulturalismeIndonesia. Jur nal Antropologi Sosial Budaya Etnovisi, 2 (1), 3-10.

Zahara, Idris. 1987. Dasar-Dasar Kependidikan.Padang: Angkasa Raya. 